\title{
ESTABLISHING THE ROLE OF AMPHIBIANS (ANURA) IN THE PROPHYLAXIS OF HELMINTHS SPECIFIC TO DOMESTIC, WILD AND PET ANIMALS
}

\author{
Elena Gherasim, Dumitru Erhan, Ștefan Rusu
}

\author{
Institute of Zoology, Chișinău, Republic of Moldova
}

e-mail: gherasimlenuta@gmail.com

\begin{abstract}
This work is based on helminthological data of amphibians, collected since 2013 until 2020, in the Republic of Moldova. The investigations on anura amphibians were conducted in the laboratory of Parazitology and Helminthology of the Institute of Zoology. One of the most common parasitic diseases in ruminants is fasciolosis, caused by the trematode Fasciola hepatica species. The results of parasitological research showed that adult cattle were infected with fascioles in $66.4 \%$ of cases, and young cattle - in $46.1 \%$ of cases. This is largely due to the grazing of animals of different species and ages in limited areas. The presence of the trematode species Haplometra cylindracea was established in $78 \%$ of cases in the amphibians in the Ranidae and Bufonidae families (Rana ridibunda, Rana lessonae, Rana temporaria, Bufo viridis). The results of laboratory helminthological investigations have shown that the relationships between the Fasciola hepatica miracidium and the Haplometra cylindracea miracidium are antagonistic. Amphibians of the Ranidae and Bufonidae families (Rana ridibunda, Rana lessonae, Rana temporaria, Bufo viridis) infested with Haplometra cylindracea tremateda may play an important role in the prophylaxis of fasciolosis.
\end{abstract}

\section{Introduction}

The most common helminths in domestic, wild and domestic animals are ecto-endoparasitosis, which causes them major economic damage [2]. The main biotic and abiotic factors (biological properties of parasite species, specific diversity and numerical efficiencies of hosts, thermal conditions, humidity, etc.) determine the existence and functioning of the main groups of endo- and ectoparasites in agrocenoses and in the natural biotopes.

Helminthological research performed on adult cattle, depending on the maintenance technology and the geographical area, has shown that they are infested with Fasciola hepatica in $34.8-48.2 \%$ of cases. In the body of cattle infested with Fasciola hepatica there are considerable changes in the liver and muscle tissue of the content of vitamins (A, C, B1, B6, E), microand macroelements $(\mathrm{Ca}, \mathrm{Mn}, \mathrm{Na}, \mathrm{K}, \mathrm{Fe}, \mathrm{P})$, leading to a considerable decrease in the quality of these products $[2,3]$.

Animal infestation occurs through the consumption of Fasciola hepatica adolescarium (infesting form), either with grazing or drinking water from biotopes favorable to fasciolosis.

The presence and circuit of the parasitic agent in the body of ruminants, causes essential changes in metabolism, digestive system, decreases the ability to assimilate food, which leads to weakening the body, decreased productivity, daily weight gain, and sometimes their death [5].

Ruminants or productive animals are the definitive hosts of the Fasciola hepatica species, but in the development cycle of this species also participate some mollusks species of the genus Lynmaea, which are an important source of food for amphibians. 
The ecaudata amphibians can be definitive optional hosts in the development cycle of various helminth species (Haplometra cylindracea, Alaria alata, Spirometra erinacei-europaei, etc.), dangerous for the animals and humans $[1,6,7]$.

\section{Materials and methods}

In order to identify the role of amphibians in the biological prophylaxis of helminths in animals, laboratory helminthological investigations of biological samples of amphibians were performed, on the presence of helminths or helminthic elements (eggs, larvae), which contribute to the formation and maintenance of common parasitic foci domestic, wild and pet animals.

Observation, collecting and obtaining data on the complex of anurans from Ranidae (Rana ridibunda, $R$. lessonae, $R$. esculenta, $R$. temporaria, $R$. dalmatina) and Bufonidae (Bufo bufo, $B$. viridis) families was performed in the center and south of Moldova.

The helminthological analysis of biological samples was performed according to the standard method proposed by K.I. Skrjabin, which involves the examination of all the internal organs of the animal [9].

Helminthological research of the parenchymal organs was performed with the help of compressors, and the digestive tract - by successive washes.

The collection, fixing, determination and processing of the helminthological material was carried after the methods proposed by various authors $[6,7,8]$.

The diagnosis of the helminthosis in ruminants was established on the basis of complex parasitological research, with evidence of clinical manifestations of the disease, epizootiological, helminthocoproscopic, pathological and anatomical data, dissection of corpses, dissection of carcasses of slaughtered animals at meat slaughterhouses and in households. For the diagnosis of the fasciolosis in living condition were used the method of successive washing of biological samples, the methods described by Demidov, Vişncauscas, Darling and others [5].The miracidium of Fasciola hepatica and Haplometra cylindracea were obtained in laboratory conditions, in the Laboratory of Parasitology and Helminthology of the Institute of Zoology.

Fasciola hepatica eggs were placed in a thermostat at the temperature of $24-26^{\circ} \mathrm{C}$ during 10 days, after which, Fasciola hepatica miracidium were obtained.

Haplometra cylindracea miracidium were obtained by examining all the internal organs of the amphibians (Rana ridibunda Rana lessonae, Rana temporaria, Bufo viridis), by applying methods specific to the field of research. The Haplometra cylindracea specimens were kept alive in the thermostat, at a constant temperature of $24-26^{\circ} \mathrm{C}$, in physiological solution.

In order to quantify the characteristics of helminthes contamination, the intensity indexes (II, specimens) was calculated - the minimum and maximum number of parasites of a species and the extent of invasion (EI, \%) - the percentage of host contamination by a parasite species.

\section{Results and discussions}

Previous parasitological research has shown that adult cattle were infected by fascioles in $66.4 \%$ of cases and young cattle in $46.1 \%$ of cases [2]. This is largely due to the grazing of animals of different species and ages in limited areas. 
From the body of ruminants infested with Fasciola hepatica (cattle), in the environment (pasture) eggs are eliminated, which reach the body of the species of mollusks Lymnaea truncatula - freshwater snail, which at the optimum temperature $\left(18-25^{\circ} \mathrm{C}\right)$, inhabits in swampy areas. If the egg hit into a wet area, within 9-14 days the larva emerges - miracidium. The vitality of the larva is several hours, maximum 2-3 days, resembles a ciliate, has cilia, which move very quickly and have a special tactics for snails. This is a mandatory stage for the evolution of the helminth, apart from which the larvae cannot become contagious to cattle.

In the snail, the miracidium transforms into sporocyst 1 . It divides into sporocyst 2 , then into redia, redia-daughter, migrates into the hepatopancreas of the snail, where it transforms into a cercariae. The cercariae form the digestive tract and have a tail.

From a snail, in general, several hundred cercariae are eliminated. After coming out of the snail, the cercariae are fixed on the grass, with the help of cystogenic glands, which secrete a shell and turn into a larva trapped under the name of adolescaria. Their cycle lasts 2-2.25 months. Adolescaria are very resistant to the environment (they have a cystic form), they resist on the grass until autumn (the disease has a higher frequency in autumn).

Cattle become infected with Fasciola hepatica either when grazing grass with adolescarias in wet habitats, or by eating already infested hay. Once in the liver, it passes through the Glisson's capsule, which is sifted through the places where it crosses the young bundles due to its mechanical (cell breakage) and toxic action. The host organism (cattle), after 2-3 months, begins to remove eggs. The biological cycle of the trematode species Fasciola hepatica lasts about 5-6 months [3].

At the sanitary-veterinary expertise of the carcasses and organs, depending on the intensity of the fascioles infestation, it is recommended to establish three levels of infestation: small, medium and high.

The low level of infestation is detected in case of liver damage with a single specimen of fasciola (10-15\%). At this level, as a rule, no visible changes are established on the surface and in the section of the liver parenchyma; when the bile ducts are suppressed, unique fascioles are removed from them. The low level of infestation is found in young people aged 2-3 years $(25-28 \%)$.

The average level of infestation is detected when visually the damage is found not more than $2 / 3$ of the organ. The section shows live fascioles and partial thickening of the bile duct walls with catarrhal inflammation of the affected part of the liver. Usually, this level is observed in animals aged 3-5 years (22-26\%).

High level of infestation - the whole organ is affected. The liver swells and is hyperimulated, when touched the walls of the bile ducts are strongly thickened; their inner surface is rough due to the excessive growth of connective tissue; affected sections with dark red spots, coagulated blood and fascioles of different sizes (up to 1000 and more specimens) are detected in the section. The high level of infestation is characteristic for adult cattle aged 6-7 years and over (14-18\%). Thus, in animals slaughtered more frequently, the medium and low intensity of infestation was detected. 
The results obtained show that in cattle with low intensity of fasciole infestation, the moisture content in meat increases by $2.45 \%$, average - by $3.53 \%$, in those with increased infestation intensity - by $5.84 \%$, and in the liver, respectively - by $2.44 \%, 5.59 \%$ and $9.46 \%$.

In cattle with low infestation intensity, the dry matter content in meat decreased by $6.82 \%$, average - by $9.85 \%$, increased - by $16.67 \%$, and in liver, respectively - by $5.63 \%, 12.91 \%$ and $21.85 \%$. The amount of protein in meat, in cattle with low infestation intensity, decreased by $3.23 \%$, average - by $5.53 \%$ and in those with increased infestation intensity - by $8.3 \%$, and in the liver, respectively - by $6,01 \%, 9.87 \%$ and $16.31 \%$. In cattle with low infestation intensity, the fat content in meat decreased by $25.74 \%$, average - by $28.57 \%$ and increased - by $65.74 \%$, and in the liver, respectively - by $2.27 \%, 29.55 \%$ and by $56.82 \%$.

In cattle with low infestation intensity, the amount of mineral substances in meat decreased by $16.67 \%$, average - by $16.67 \%$ and increased - by $25 \%$, and in liver, respectively - by $7.14 \%$, $14.29 \%$ and by $28.57 \%$.

In order to determine the nutritional value of muscle tissue and liver in cattle infested with fascioles, the content of vitamins (A E, B1, B2, C), micro- and macroelements (Ca, Mg, Na, K, $\mathrm{Fe}, \mathrm{P})$ was determined. It was established that in cattle infested with fascioles, the content of vitamin $\mathrm{A}$ in the liver decreased by 1.4 times, E - 3.18, B1 and B2 - 1.08 and 1.23, respectively, and $\mathrm{C}-2.08$ - 3.01 times, phosphorus - 4.17, calcium - 1.56, $\mathrm{Mg}-1.04$, and the $\mathrm{Na}$ and $\mathrm{K}$ content increased by 1.61 and 1.25 times, respectively, compared to uninfested animals.

In meat, the content of vitamin A was 1.83 times lower, E - 1.67, B1 -1.21, B2 - 1.11, C 3.73, calcium - 1.60, phosphorus - 1, 46, and magnesium, sodium, potassium and iron - respectively $1.34,1.82,1.30$ and 3.14 times higher than in healthy animals. In the treatment of this disease are recommended various remedies of chemical origin (Albendazole, Closantel, Clorsulon, Triclabendazole, Oxyclozanide, etc.), to which over time the fascioles become resistant.

The role of ecaudata amphibians (Rana ridibunda, Rana lessonae, Rana temporaria, Bufo viridis) in the biological control of ruminant fasciolosis is explained by the fact that they are definitive hosts of the trematode species Haplometra cylindracea which in the cercariae stage parasitizes in the snail species Lymnaea truncatula - intermediate hosts for the species Fasciola hepatica.

Both parasites, meeting in the same host (Lymnaea truncatula), the species of trematode Haplometra cylindracea is antagonistic to the species Fasciola hepatica, causing the death of the larval stages of the fasciola. Snails of the genus Lymnaea, as intermediate hosts, have an aquatic and semi-aquatic way of life, so that they can be found in stagnant waters or humid environment (swamps), a favorable living environment for amphibians as well.

The amphibian species Rana ridibunda, Rana lessonae, Rana temporaria and Bufo viridis inhabit the most diverse biotopes, including aquatic basins, where the biological cycle of Fasciola hepatica takes place.

According to helminthological investigations performed on amphibians, their infestation was established in $78 \%$ of cases with the trematode species Haplometra cylindracea Zeder, 1800 from the Plagiorchiidae family. 
Thus, the antagonistic relations between these two species of parasitic agents end with the interruption of the developmental cycle, of the larval stages (sporocyst, redia, redia-daughter, cercarium), of the Fasciola hepatica trematode in the intermediate host Lymnaea truncatula and later the interruption of its vehicular chain in biotopes.

The studies were carried out within the research project 20.80009.7007.12 and in the scholarship program offered by the World Federation of Scientists, Geneva 2020-2021

\section{Conclusion}

1. The results of parasitological research showed that adult cattle were infected with fascioles in $66.4 \%$ of cases, and young cattle - in $46.1 \%$ of cases. This is largely due to the grazing of animals of different species and ages in limited areas.

2. The presence of the trematode species Haplometra cylindracea was established in $78 \%$ of cases in the amphibians in the Ranidae and Bufonidae families (Rana ridibunda, Rana lessonae, Rana temporaria, Bufo viridis).

3. The results of laboratory helminthological investigations have shown that the relationships between the Fasciola hepatica miracidium and the Haplometra cylindracea miracidium are antagonistic.

4. Amphibians of the Ranidae and Bufonidae families (Rana ridibunda, Rana lessonae, Rana temporaria, Bufo viridis) infested with Haplometra cylindracea tremateda may play an important role in the prophylaxis of fasciolosis.

\section{Bibliography}

1. Euzeby, J, Les zoonozes parasitaires d'origine amphibienne et ophidienne. En: Sci. Vet. Med. Сотр., 1984, Vol, 86, nr. 3, p, 71-75.

2. Erhan D. Epizootologia mono- şi poliinvaziilor la bovine în Republica Moldova în funcţie de zonă, vârstă şi tehnologia de întreţinere //In: Mediul Ambiant, 2009, nr.5(47), p. 37-41.

3. Iacub Olimpia C. Parazitologia şi clinica bolilor parazitare la animale. Helmintoze. Editura "Ion Ionescu de la Brad" Iaşi, 2016, 513 p.

4. Olteana Ch., Panaite D., Gherman I., etc. Poliparazitismul la om, animale, plante şi mediu. -Bucureşti, Editura "Cereş” 2001. - 819 p.

5. Абуладзе К. И., Демидов Н. В., Неплоконов А.А. паразитология и паразитарные болезни сельскохозяйственных животных. Мосва, 1990, 464 с.

6. Гашев С. Н. и др. Зооиндикаторы в системе регионального экологического мониторинга Тюменской области: методика использования. Тюмень: изд-во Тюменского гос. ун-та, 2006. 132 c.

7. Кузмин, С.Л. Земноводные бывшего СССР. Издание второе, переработанное. Москва, 2012. $327 \mathrm{c}$.

8. Рыжиков К. М., Шарпило В. П. Шевченко Н. Н. Гельминты амфибий фауны СССР. М., 1980. 279 c.

9. Скрябин К.И. Метод полных гельминтологических вскрытий позвоночных, включая человека. М., 1928. 45 с. 